\title{
Efektivitas Desensitizing Agent dengan dan tanpa Fluor pada Metode in Office Bleaching terhadap Kandungan Mineral Gigi (Kajian In Vitro)
}

\author{
* Yulita Kristanti *, Widya Asmara**, Siti Sunarintyas ${ }^{* * *}$, Juni Handajani ${ }^{* * * *}$ \\ *Bagian Ilmu Konservasi Gigi, Fakultas Kedokteran Gigi, Universitas Gadjah Mada \\ **Bagian Mikrobiologi, Fakultas kedokteran Hewan, Universitas Gadjah Mada \\ ***Bagian Biomaterial, Fakultas Kedokteran Gigi, Universitas Gadjah Mada \\ ****Bagian Biologi Mulut, Fakultas Kedokteran Gigi, Universitas Gadjah Mada \\ JI Denta no 1, Sekip Utara, Yogyakarta, Indonesia; e-mail: yulitakristanti@ugm.ac.id.
}

\begin{abstract}
ABSTRAK
In office bleaching menggunakan hidrogen peroksida $40 \%$ sering memberikan efek samping berupa linu baik selama maupun setelah perawatan tersebut dilakukan. Penelitian ini dilakukan dengan tujuan untuk mengetahui pengaruh waktu aplikasi dan kandungan fluor desensitizing agent pada metode in office bleaching terhadap kandungan mineral gigi. Delapan gigi masing-masing dipotong menjadi 4 bagian, 6 potong digunakan untuk pemeriksaan XRD awal. Gigi dikeringkan dalam oven suhu $50^{\circ}$ selama 30 menit diserbuk, diambil $1 \mathrm{mg}$ untuk diperiksa kandungan mineralnya dengan goniometer. Dua puluh empat potong yang lain dibagi dalam 4 kelompok perlakuan. Kelompok I: gigi diaplikasi bahan bleaching 0,5-1 mm hidrogen peroksida 40\% selama 1 jam, dicuci, dikeringkan, diikuti aplikasi 0,1 ml desensitizing agent tanpa fluor (CPP-ACP) selama 30 menit, dicuci, dikeringkan. Kelompok II : gigi diaplikasi CPP-ACP 30 menit, dicuci, dikeringkan, dibleaching menggunakan hidrogen peroksida 40\% selama 1 jam. Selanjutnya gigi diaplikasi CPP-ACP 30 menit lagi, dicuci, dikeringkan. Kelompok III gigi dibleaching menggunakan hidrogen peroksida $40 \%$ selama 1 jam, dicuci, dikeringkan, diikuti aplikasi desensitizing agent yang mengandung fluor (CPP-ACFP) selama 30 menit, dicuci, dikeringkan. Kelompok IV: gigi diaplikasi CPP-ACFP 30 menit, dicuci, dikeringkan, dibleaching menggunakan hidrogen peroksida 40\% selama 1 jam. Selanjutnya gigi diaplikasi CPP-ACFP selama 30 menit, dicuci dikeringkan. Sesudah perlakuan, semua gigi dilakukan pemeriksaan kandungan mineral gigi dengan prosedur yang sama. Uji Mann Whitney menunjukkan penurunan mineral paling sedikit terjadi pada kelompok IV (4500). Desensitizing agent mengandung $\mathrm{F}$ sebelum dan sesudah perlakuan in office bleaching menunjukkan penurunan mineral paling kecil
\end{abstract} Maj Ked Gi. Desember 2014; 21(2): 136 - 140

Kata Kunci : desensitizing agent, fluor, in office bleaching, kandungan mineral

ABSTRACT: The Effectiveness of Desensitizing Agent with and without Fluorine in Office Bleaching Method to Tooth Mineral content. Tooth sensitivity arises during or after an in-office bleaching was performed is usually overcome by using desensitizing agent with or without fluor. So far, desensitizing method applied only reduces tooth sensitivity but it had not overcome demineralization problem yet. This study was aimed to determine the influence of an application process and fluoride containing desensitizing agent in tooth mineral lossEight teeth were divided into four parts. Six specimens were smoothened using agate mortar. One mg of powder was inserted into the sample holder and mounted on goniometer heads to examine mineral content before treatment using $X$-Ray Diffraction (XRD). Twenty-four specimens were classified into four groups. In group I, $0,1 \mathrm{ml}$ desensitizing agent without fluoride (CPP-ACP) was applied for 30 minutes after an in-office bleaching using 40\% Hydrogen Peroxide was performed, while in group II, CPP-ACP was applied before and after an in-office bleaching was performed. In group $111 \mathrm{l}, 1 \mathrm{ml}$ fluoride containing desensitizing agent (CPP-ACFP) was applied for 30 minutes after in-office bleaching using 40\% Hydrogen Peroxide was performed, while in group IV fluoride containing desensitizing agent was applied before and after an in-office bleaching was performed. Finally, all of the specimens were measured in their after-treatment mineral contain. Mann Whitney test showed that the lowest mineral lost was detected in group IV (4500). Fluoride containing desensitizing agent applied before and after an in-office bleaching effectively reduced mineral loss.

Maj Ked Gi. Desember 2014; 21(2): 136 - 140

Keywords: desensitizing agent, in office bleaching, surface characteristics, mineral loss 


\section{PENDAHULUAN}

Maraknya perkembangan teknologi akhirakhir ini membuat akses informasi mudah didapatkan. Hal ini berpengaruh terhadap gaya hidup masyarakat, satu diantaranya dalam kaitannya dengan kepedulian pada permasalahan estetik. Pemutihan gigi adalah salah satu aspek dalam kedokteran gigi estetik yang cukup banyak diminati masyarakat. Gigi yang putih, sehat dan terawat memberi kesan tersendiri pada penampilan seseorang. Diantara berbagai teknik pemutihan gigi, in-office bleaching adalah teknik yang paling disukai oleh karena hasilnya cepat terlihat dan waktu relapsnya lebih panjang. Salah satu kelemahan teknik ini adalah penggunaan hidrogen peroksida konsentrasi tinggi yang digunakan pada teknik ini seringkali menimbulkan rasa linu baik selama maupun sesudah perawatan. Rasa linu diatasi menggunakan desensitizing agent, baik yang mengandung fluor (CPP-ACFP) maupun tidak (CPP-ACP). Hasil penelitian Dahl menunjukkan rasa linu ini dapat berlangsung 4-39 hari. ${ }^{1}$ Calcium Phosphopeptide-Amorphous Calcium Phosphate CPP-ACP mengurangi sensitivitas gigi dalam 15 menit pertama namun tidak efektif setelah satu minggu. ${ }^{2} \mathrm{Hal}$ ini menunjukkan adanya persoalan lain di luar sensitivitas yang lebih mendasar dan perlu diwaspadai, yaitu persoalan demineralisasi. Sensitivitas gigi pasca bleaching yang sudah terkendali bukan merupakan indikator bahwa remineralisasi yang terjadi pada gigi tersebut telah mencapai kondisi seperti sebelum bleaching. Peneliti lain mengatakan hidrogen peroksida $35 \%$ menyebabkan kerusakan odontoblas, menurunnya aktivitas metabolik sel, jumlah sel, mengecilnya ukuran sel dan menipisnya prosesus sitoplasmik. ${ }^{3}$ Kerusakan odontoblas yang tidak dapat diperbaiki menyebabkan lapisan dentin reparatif menjadi atubuler, sehingga terjadi inclusion cell dan selanjutnya hancur meninggalkan dead tract yang memudahkan bakteri atau bahan kimia penetrasi ke dalam pulpa. ${ }^{4,5}$

Lebih lanjut dikatakan bahwa CPP-ACP yang diaplikasikan selama 20 menit dapat mengembalikan $\mathrm{CaPO}_{4}$ yang hilang sebesar 45\%, sedangkan CPP-ACFP 31,7\%. ${ }^{6}$ Calcium Phosphopeptide-Amorphous Calcium Phosphate
(CPP-ACP) yang diaplikasikan dua kali sehari selama 3 menit remineralisasi maksimal tercapai pada hari ke-35. ${ }^{7}$ Hal ini menunjukkan persoalan demineralisasi perlu diselesaikan walaupun secara klinis timbulnya sensitivitas gigi pasca in office bleaching dapat bervariasi. Penelitian ini dilakukan dengan tujuan untuk meminimalkan mineral yang hilang akibat pemakaian bahan bleaching dengan pendekatan preventif dan kuratif, yaitu mengaplikasikan desensitizing agent sebelum dan sesudah in office bleaching dilakukan.

\section{METODE PENELITIAN}

Penelitian ini dilakukan setelah mendapatkan persetujuan dari Komisi Etik Fakultas Kedokteran Gigi Universitas Gadjah Mada. Delapan gigi premolar satu maksila masing-masing dibelah menjadi 4 bagian, enam potong digunakan untuk pemeriksaan kandungan mineral awal menggunakan X-Ray Diffraction (XRD), 24 potong dibagi dalam 4 kelompok perlakuan. Enam gigi yang diperiksa kandungan mineral awalnya dimasukkan oven suhu $50^{\circ} \mathrm{C}$ selama 30 menit, dihaluskan menggunakan agaate mortar, kemudian 1 mg untuk dimasukkan ke dalam sample holder dan diletakkan pada goniometer head. Penembakan spesimen dilakukan pada $2 \Theta$ dimulai dari sudut $5^{\circ}$ sampai $70^{\circ}$ selama 20 menit. Spektrum yang dihasilkan dicocokkan dengan data base International Centre for Difraction Data (ICDD). ${ }^{8,9,10}$

Dua puluh empat potong gigi dibagi dalam 4 kelompok perlakuan, masing-masing terdiri atas 6 potong gigi. Kelompok I potongan gigi diaplikasi 0,5$1 \mathrm{~mm}$ hidrogen peroksida $40 \%$ selama 1 jam, dicuci dikeringkan dilanjutkan dengan aplikasi $0,1 \mathrm{ml}$ CPP-ACP menggunakan spuit injection selama 30 menit, dicuci dikeringkan. Kelompok II potongan gigi diaplikasi 0,1 ml CPP-ACP selama 30 menit, dicuci, dikeringkan, diaplikasi 0,5-1 $\mathrm{mm}$ hidrogen peroksida $40 \%$, dicuci dikeringkan dan diakhiri dengan aplikasi 0,1 ml CPP-ACP selama 30 menit, dicuci, dikeringkan. Kelompok III potongan gigi diaplikasi 0,5-1 $\mathrm{mm}$ hidrogen peroksida $40 \%$ selama 1 jam, dicuci, dikeringkan, diaplikasi $0,1 \mathrm{ml}$ CPP-ACFP selama 30 menit, dicuci dikeringkan. Kelompok IV potongan gigi diaplikasi $0,1 \mathrm{ml}$ CPP-ACFP selama 
Tabel 1. Kandungan Mineral Sebelum dan Sesudah in Office Bleaching (\%)

\begin{tabular}{|c|c|c|c|}
\hline Kelompok & $\begin{array}{l}\text { Kandungan Mineral } \\
\text { Awal }\end{array}$ & $\begin{array}{l}\text { Kandungan Mineral } \\
\text { Akhir }\end{array}$ & Sig \\
\hline CPP-ACP sesudah bleaching & $72,95 \pm 8,599$ & $22,88 \pm 7,559$ & 0,03 \\
\hline CPP-ACP sebelum sesudah bleaching & $81,5 \pm 7,559$ & $51,2 \pm 19,029$ & 0,03 \\
\hline CPP-ACFP sesudah bleaching & $81,2 \pm 6,682$ & $62,5 \pm 4,586$ & 0,03 \\
\hline CPP-ACFP sebelum sesudah bleaching & $69 \pm 2,191$ & $64,4 \pm 2,968$ & 0,02 \\
\hline
\end{tabular}

Tabel 2. Hasil uji Kruskal Wallis

\begin{tabular}{ll}
\hline Uji Statistik & Hidroksiapatit \\
\hline Kai kuadrat & 37,683 \\
$\mathrm{db}$ & 7 \\
$\mathrm{P}$ & 0,001 \\
\hline
\end{tabular}

Tabel 3. Hasil Uji Mann Whitney Kandungan Mineral

\begin{tabular}{lcccc}
\hline Kelompok & $\begin{array}{l}\text { CPP-ACP ssd } \\
\text { bleaching }\end{array}$ & $\begin{array}{l}\text { CPP-ACP sbl } \\
\text { ssdh bleaching }\end{array}$ & $\begin{array}{l}\text { CPP-ACFP ssd } \\
\text { bleaching }\end{array}$ & $\begin{array}{l}\text { CPP-ACFP sbl } \\
\text { ssd bleaching }\end{array}$ \\
\hline $\begin{array}{l}\text { CPP-ACP ssd bleaching } \\
\text { CPP-ACP sbl ssdh bleaching }\end{array}$ & $0,001^{*}$ & & & \\
CPP-ACFP ssd bleaching & & $0,001^{*}$ & $0,001 *$ & \\
CPP-ACFP sbl ssd bleaching & & & & 4.500 * \\
\hline
\end{tabular}

Keterangan: * ${ }^{*}$ signifikan $(p<0,05)$; sbl = sebelum; $s \mathbf{d}=$ sesudah

30 menit, dicuci, dikeringkan, diaplikasi hidrogen peroksida $40 \%$ selama 1 jam, dicuci, dikeringkan, diakhiri dengan aplikasi 0,1 $\mathrm{ml}$ CPP-ACFP selama 30 menit, dicuci, dikeringkan. Selanjutnya semua spesimen diperiksa kandungan mineral akhirnya dengan cara yang sama dengan pemeriksaan kandungan mineral awal menggunakan XRD.

\section{HASIL PENELITIAN}

Penelitian tentang efektivitas desensitizing agent dengan dan tanpa fluor pada metode in office bleaching terhadap kandungan mineral gigi dilakukan di Laboratorium Geologi Fakultas Teknik Universitas Gadjah Mada. Data kandungan mineral awal dan akhir serta standar deviasi ditampilkan pada Tabel 1.

Dari Tabel 1 terlihat bahwa kelompok yang diaplikasi CPP-ACFP sebelum dan sesudah perlakuan in office bleaching menunjukkan kehilangan mineral yang paling sedikit dibanding kelompok lain. Hal ini dapat dilihat dari kandungan mineral akhir sebesar 64,4 $\pm 2,968$ dan kandungan mineral awal sebesar $69 \pm 2,191$. Penurunan mineral paling banyak terjadi pada kelompok yang diaplikasi CPP-ACP sesudah bleaching saja, yang ditunjukkan oleh nilai kandungan mineral akhir sebesar 22,88 $\pm 7,559$ dan kandungan mineral awal sebesar 72,95 $\pm 8,599$. Data dianalisis statistik non parametrik menggunakan Kruskal Wallis (Tabel 2). Hasil uji Kruskal Wallis menunjukkan perbedaan yang bermakna $(p<0,005)$.

Selanjutnya untuk mengetahui kelompok yang mempunyai perbedaan signifikan dilakukan uji Mann Whitney seperti pada Tabel 3.

\section{PEMBAHASAN}

Tabel 3 menunjukkan bahwa terdapat perbedaan kandungan mineral awal dan akhir yang bermakna pada semua kelompok. Hal ini berarti in office bleaching menggunakan hidrogen 
peroksida $40 \%$ menyebabkan kehilangan mineral cukup banyak. Hasil ini sesuai dengan pendapat peneliti sebelumnya yang menunjukkan adanya peningkatan diameter tubulus dentinalis setelah dilakukan bleaching baik menggunakan karbamid peroksida $45 \%$, sodium perborat $30 \%$ dan $\mathrm{H}_{2} \mathrm{O}_{2}$ $35 \%{ }^{8}$ Hidrogen peroksida dapat mengubah struktur hidroksiapatit dan menyebabkan terjadinya pengurangan prosen berat kalsium serta fluor yang mengindikasikan terjadinya demineralisasi. Level kalium juga menurun pada email maupun dentin, namun sejauh ini peran kalium dalam proses demineralisasi masih belum diketahui. ${ }^{9,10}$ Hilangnya mineral dan peningkatan diameter tubulus dentinalis merupakan faktor predisposisi terjadinya reaksi di daerah servikal. ${ }^{8}$

Hasil penelitian memperlihatkan dentin peritubular lebih tahan terhadap hidrogen peroksida dibandingkan dentin intertubuluer. Hal ini kemungkinan oleh karena dentin peritubuler lebih banyak mengandung mineral dan sedikit kolagen. Sebaliknya dentin intertubuler lebih banyak mengandung kolagen, karena kolagen merupakan komponen utama dari dentin intertubuler yang menyusun $92 \%$ matriks organik. ${ }^{11}$

Kelompok yang diaplikasi desensitizing agent mengandung fluor (CPP-ACFP) menunjukkan penurunan mineral yang lebih sedikit dibandingkan kelompok yang diaplikasi desensitizing agent tanpa fluor (CPP-ACP). Hal ini menunjukkan peran $F$ yang ditambahkan ke dalam CPP-ACP cukup dominan. Hasil ini sejalan dengan pendapat yang mengatakan bahwa fluor membatasi demineralisasi dan menstimulasi remineralisasi kristal hidroksi apatit dengan dibantu oleh ion kalsium dan fosfat. ${ }^{12}$

Pada penggunaan CPP-ACP mineral yang terbentuk adalah hidroksiapatit, sedangkan pada CPP-ACFP mineral yang terbentuk adalah fluorapatit. Hal ini terjadi akibat penggantian molekul hidroksil dengan fluor dalam kristal hidroksiapatit. Fluorapatit bersifat lebih keras dan lebih tahan terhadap pelarutan oleh asam dibandingkan hidroksiapatit. ${ }^{12}$

\section{KESIMPULAN}

Desensitizing agent mengandung $\mathrm{F}$ sebelum dan sesudah perlakuan in office bleaching menunjukkan penurunan mineral paling kecil.

\section{DAFTAR PUSTAKA}

1. Dahl JE. Tooth bleaching - a critical review of the biological aspect. J. Crit. Rev. Oral Biol. Med. 2003;14(4): 292-304.

2. Walsh LJ. The effects of GC tooth mousse on cervical dentinal sensitivity: a controlled clinical trial. International Dentistry SA. 2010; 12(1): 4-12.

3. Ribeiro APD, Sacono NT, Lessa FCR, Nogueira I, Coldebella CR, Hebling J, de Souza Costa CA. Cytotoxic effect of a $35 \%$ hydrogen peroxide bleaching gel on odontoblast-like MDPC-23 cells. Oralsurg. oral med. oral pathol. oral radiol. endod. 2009; 180: 458-64.

4. Grossman LI, Oliet S, Rio CED. IImu Endodontik dalam Praktek. Ed 11. Jakarta: Penerbit Buku Kedokteran EGC; 2009: 295-7.

5. Yu C, Abbott PV. An overview of the dental pulp: its function and responses to injury. Aus. Dent. J 2007; 52(1): 4-16.

6. Jose P, Suresh M, Kavitha S, Mahalaxmi S. Mineral loss before and after bleaching and mineral uptake on application of remineralizing agent. Indian J of Multidisc. Dent. 2010; 1(1):47-50

7. Mithra $\mathrm{NH}$, Money A. Remineralization of enamel subsurface lesions with casein phosphopeptide amorphous calcium phosphate : a quantitative energy dispersive $\mathrm{x}$-ray analysis using scanning electron microscopy: an in vitro study, J. Conserv. Dent 2012; 15:61-7

8. Bish DL, Chipera SJ, Nunes H, Oakley DT. http:// www/pbadupws.nrc-gov/docs/ML00374887. pdf diakses 21/4/2013 
9. Dutrov LB, Clarck CM, R-ray Powder Diffraction (XRD). http.//sercc.carleton.edu. diakses $21 / 4 / 2013$

10. Jamalussin XRD. http://docs.google.com/documented/d diakses 23/4/2014.

11. Maleknejad F, Ameri H, Kianfar I. Effect of intra coronal bleaching agent on ultrastructure and mineral content of dentin. J. Conserv. Dent. 2012; 15(2): 174-177.

12. Cakir FY, Oztas SS, Firat E, Gurgan S. Effect of in office bleaching systems on chemical composition of enamel and dentin: an in vitro study. J. Clin. Dent. Res. 2012; 36(3): 35-41.
13. Rotstein I, Danker E, Goldman A, Heling I, Tabholz A, Zalkind M. Histochemical analysis of dental Hard tissues following bleaching. J. Endod. 1996; 22: 23-5.

14. Chng HK, Ramli YM, Yap AUJ, Lim CT. Effect of hydrogen peroxide on intertubular dentine, J.of Dentistry. 2005; 33: 363-9.

15. Roberts MW, Wright JTW. The dynamic process of demineralization and remineralization. J. Dimension of Dental Hygiene. 2009: 16-21. 